\title{
THE CASTILLEAE, A TRIBE OF THE MORACEAE, RENAMED AND REDEFINED DUE TO THE EXCLUSION OF THE TYPE GENUS OLMEDIA FROM THE "OLMEDIEAE"
}

\author{
C. C. BERG \\ Instituut voor Systematische Plantkunde, Utrecht
}

\section{SUMMARY}

New data on cladoptosis in the group of Moraceae which was known up to now as the tribe Olmedieae led to a reconsideration of the position of Olmedia, Antiaropsis, and Sparattosyce. The remainder of the tribe is redefined and is named Castilleae.

\section{INTRODUCTION}

The monotypic genus Olmedia occupies an isolated position within the neotropical Olmedieae. Its staminate flowers have valvate tepals, inflexed stamens springing back elastically at anthesis, and sometimes well-developed pistillodes. Current anatomical research on the wood of Moraceae (by Dr. A. M. W. Mennega) and recent field studies (by the present author) revealed that Olmedia is also distinct in anatomical characters of the wood and because of the lack of self-pruning branches. These differences between Olmedia and the other representatives of the tribe demand for reconsideration of the position of the genus and the delimination of the tribe.

The genus Olmedia was described by Rulz \& Pavon (1794). The original description mentioned that the stamens bend outward elastically at anthesis. Nevertheless it was placed in the "Artocarpeae" (cf. ENDLICHER 1836-1840; TRÉCUL 1847), whereas it should have been placed in the "Moreae" on account of the characters of the stamens which were rather exclusively used for separating the two taxa. Remarkably Trécul (1847) in his careful study on the "Artocarpeae" disregarded the (described) features of the stamens.

The tribe Olmedieae was established by TRÉCUL in 1847. Its circumscription has remained essentially unchanged notwithstanding later classificatory work (cf. EICHLER 1875; Baillon 1875-1876; Bentham \& HoOKer 1880; ENGLeR 1889; CORNER 1962). This is mainly due to the fairly distinct features of the inflorescences. Characters of the inflorescences have played an important part in subdividing the Moraceae, and in Corner's classification (CORNER 1962) they dominate. According to him the inflorescence furnishes the only satisfactory characters for a primary subdivision of the family.

The inflorescences of the Olmedieae are unisexual and have a discoid (to hemispherical or to urceolate) receptacle provided with an involucre formed by basally attached (for the greater part) imbricate bracts. These features unite 
the neotropical genera Olmedia, Pseudolmedia, Perebea, Maquira, Castilla, Helicostylis, and Naucleopsis (cf. BERG 1972) as well as the paleotropical genera Antiaris, Mesogyne, and Antiaropsis (cf. CORNER 1962). Sparattosyce, also placed in the Olmedieae by CORNER (1962), lacks an involucre.

\section{INFLORESCENCES}

There are some cases shedding doubt on the value attached to inflorescence characters for delimitating the tribes of the Moraceae. The inflorescences of Bleekrodea (Streblus sect. Bleekrodea sensu CORNER 1962), a genus placed in the Moreae sensu Corner, and the inflorescences of Utsetela and Helianthostylis, both members of the Brosimeae sensu Corner, are distinctly linked in their structure and do not seem to be essentially different. Phyllochlamys (Streblus sect. Phyllochlamys sensu CORNER 1962), a member of the Moreae, has capitate and involucrate inflorescences. According to Corner the capitate inflorescences of Phyllochlamys may be regarded as a result of condensation of racemes. The pistillate inflorescences of Trophis involucrata Burger (1973), another member of the Moreae, are also capitate and involucrate. The staminate inflorescences of this species are racemose. Trophis involucrata belongs to a genus the other species of which have spicate to racemose pistillate inflorescences. As indicated by the latter two cases, spicate to racemose and capitateinvolucrate inflorescences are morphologically close. These two cases could indicate that other taxa which are now placed in distant positions in the systems of the Moraceae may eventually prove to be closely related too.

\section{STAMINATE FLOWERS}

The distinctive staminate flowers of Olmedia aspera (inflexed stamens bending outwards elastically at anthesis, valvate tepals, and the occurrence of welldeveloped pistillodes) by themselves do not lead to reconsideration of the position of the genus.

Inflexed stamens, common in the Moreae s.l. (cf. BERG 1973) and distinctive for the Urticaceae, do not seem to be of value for separating taxa of higher than generic rank (cf. CORNER 1962; BERG 1973). In the Moreae there are several examples of pairs of probably or certainly related taxa one of which has inflexed stamens, the other straight stamens (e.g., Trophis - Sorocea, Prainea Malaisia. Maclura - Cudrania, Chlorophora excelsa - Bagassa guianensis). Pistillodes commonly occur in groups with inflexed stamens, less commonly or rarely in groups with straight stamens. The latter usually show reductions in the staminate flowers (number and size of the tepals, number of the stamens, and dimensions of the vestiges of the other sex) or even disorganisation of the flower. In the Moraceae with inflexed stamens staminate flowers with valvate tepals are known in Trophis s.str., Bleekrodea, and Fatoua. However, in certain closely related taxa like respectively Sorocea and Sloetiopsis the tepals are decussate-imbricate. 


\section{WOOD ANATOMY}

Anatomical features of the wood set Olmedia apart from the other members of the Olmedieae, as far as examined. This subject is treated in detail by MENNEGA \& LANZING-VINKENBORG (1977).

\section{SELF-PRUNING BRANCHES}

Shedding of branches in members of the Olmedieae was reported for the first time in a note by LYNCH (1877) on disarticulation of branches for Castilla elastica and Antiaris. For Castilla elastica the phenomenon was more accurately described by WENT (1897), although it has come to general attention largely through the studies of COOK $(1903,1911)$. Shedding of branches in Antiaris was also reported by TRIMEN (1898) and DE WIT (1963). Furthermore, the presence of self-pruning branches is known in Helicostylis tomentosa and Perebea xanthochyma (cf. BERG 1972).

Cladoptosis is a feature of the trees referred to the "Model of Cook", one of the categories distinguished by Hallé \& OLDEMAN (1970) in their study dealing with the architecture and growth of tropical trees. Trees referred to this model are characterized by a monopodial orthotropous trunk bearing the leaves in spirals and the branches in a continuous order. The branches with distichous leaves in several aspects are reminiscent of leaves (dorsiventrality, limited growth, shedding).

The large-leaved Naucleopsis ulei (ranging from the Amazon Basin through Colombia to Panama) completely matches these features. The small trees mostly bear only almost horizontal spirally arranged self-pruning branches. Young trees of Castilla elastica (and C. ulei) are similar to the trees of N. ulei, but with age they form permanent branches departing at more acute angles than the self-pruning branches. These permanent branches bear their leaves in spirals and also bear self-pruning branches, like the trunk. In this species relatively few permanent branches are formed.

The self-pruning branches may bear secondary lateral branches, which are often shed before the primary. When shed the basal part of the branch is reminiscent of a phallus (and may be a source of bawdy jokes). It leaves a concave scar with radiating ridges (see fig. I). Inflorescences are (for the greater part) borne on the self-pruning branches.

Other large-leaved Olmedieae like Perebea guianensis and $P$. mollis resemble $C$. elastica in habit. The self-pruning branches of the large-leaved species may reach a length of $2.5-3.5 \mathrm{~m}$ (observed in $P$. mollis, and reported for $C$. elastica by CooK 1903); at the base they may be ca. $5 \mathrm{~cm}$ in diameter.

The small-leaved Olmedieae, like several species of Pseudolmedia. Maquira, Naucleopsis, Perebea, and Helicostylis, usually have a denser system of partly thinner and repeatedly ramified permanent branches. The self-pruning branches are smaller (up to ca. $1 \mathrm{~m}$ long and up to $\mathrm{ca} .1 \mathrm{~cm}$ in diameter). The self-pruning branches in this small-leaved species are more commonly ramified than in the large-leaved species with their thicker self-pruning primary branches. 

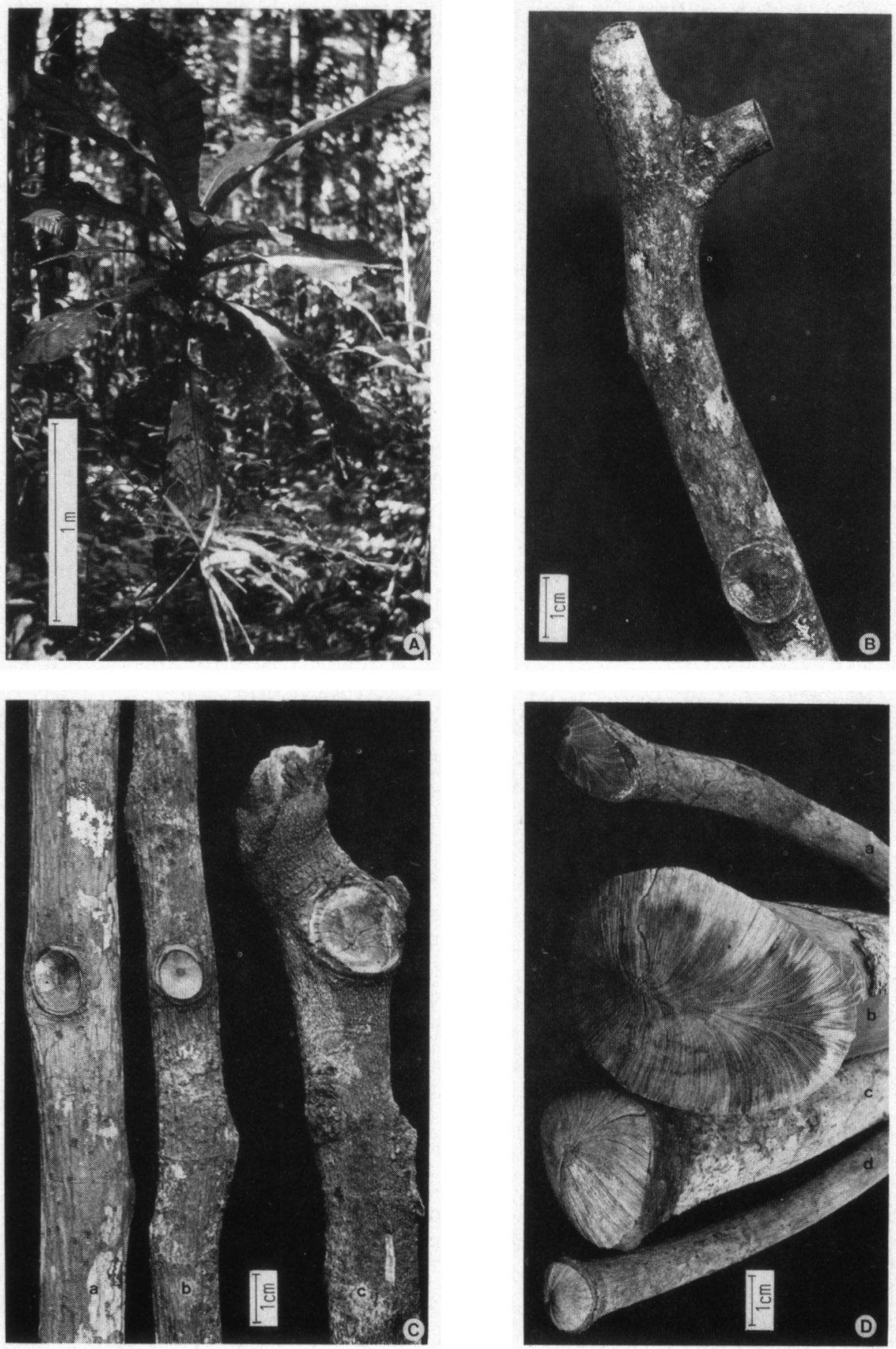
According to Hallé and Oldeman's system the small-leaved species should be placed in the "Model of Roux", to which the two authors also referred Perebea guianensis. The differences in the architecture between large-leaved and small-leaved species are not esssential, but gradual and apparently correlated with the dimensions of the leaves. The two models (Cook's and Roux') are related, as can be gleaned from the study of Hallé and Oldeman.

Naucleopsis stipularis, a common species of the undergrowth of rain forests in the Upper Amazon Basin (in Brazil), is a rosette-tree with (up to $75 \mathrm{~cm}$ long) large leaves (see fig. 1). It occasionally forms permanent branches. Except for the lack of self-pruning branches this species resembles $N$. ule $i$ in its habits (and habitat). This indicates an (occasional?) relationship between Hallé and Oldeman's "Models of Cook and Roux" and their "Model of Corner".

Beside Antiaris welwitschii and Perebea guianensis Hallé and Oldeman also classed Chlorophora spec. (Iroko) under the "Model of Roux". This Chlorophora species is $C$. regia. It should be regarded as distinct from Antiaris and Perebea because of the lack of abscission of branches as occurring in these genera. Moreover, C. regia appears to lose the features of the "Model of Roux" when becoming adult. Then its tree-form is quite similar to that of its close relative, C. excelsa, which shows the features of the "Model of Troll" already in sapling stage. Many Moraceae, mainly of the tribes Moreae s.l. and Dorstenieae s.l. (cf. BERG 1973), have to be referred to the latter model. One of them is Olmedia aspera. It clearly exhibits sympodial growth and bears the leaves in two rows, even on the main branches of the tree.

Nothing is known about habit, growth, and cladoptosis in Mesogyne, a monotypic African genus closely related to Antiaris, nor about Antiaropsis (New Guinea) and Sparattosyce, both monotypic genera placed in the Olmedieae (cf. CORNER 1962). There are no indications that self-pruning branches occur in other groups of Moraceae.

Cladoptosis is a widely spread phenomenon in woody plants, as shown by Hallé and Oldeman's study and the review of this subject by MiLlington \& CHANEY (1973).

Anatomical details of the abscission of branches in "Olmedieae" are treated by KoEK-NOORMAN and TER WELLE in the Leiden Botanical Series, Nr. $3 ; 1976$.

\section{BUDS}

LYNCH (1877) reported for Castilla elastica the occurrence of dormant buds beside the bases of the self-pruning branches. According to WeNT (1897) the

Fig. 1. A. Habit of Naucleopsis stipularis; B. part of permanent branch with basal part of self-pruning branch and healing branch scar (Perebea mollis, Mennega \& Koek 866); C. scars of abscised branches (a and b, Perebea guianensis, Prance et al. 18131 ; c. Pseudolmedia murure, Prance et al. 19864); D. bases of abscised branches (a, Helicostylis Prance et al. 18613 b, c, and d. Perebea mollis). 
lower nodes of the young plants of $C$. elastica only form a single bud in the middle of the leaf axil. When the top of the plants is cut, these buds may develop into branches resembling the stem. From the 10th to 12 th node two buds can be found in the axils of the leaves. The median bud forms a self-pruning branch. The lateral (dormant) bud may develop into a permanent branch (with characters similar to those of the stem) after the top of the plant of the self-pruning branch has been cut. Buds next to the base of self-pruning branches were found by the author in some herbarium collections (of Perebea xanthochyma, Perebea guianensis, Maquira costaricana). Judging from the scarce material examined (see fig. 2) and the illustration given by LYNCH (1877) the lateral bud might prove to be the lower most bud of the self-pruning branch. In Antiaris permanent branches may arise from an accessory axillary bud above the base of the selfpruning branches (see fig. 2).

The occurrence of additional (dormant) buds to produce permanent branches appears to be an essential feature in this group, and possibly in other groups with self-pruning branches, too.

\section{THE TRIBE CASTILLEAE}

Using presence of septate wood fibres and self-pruning branches as important criteria for delimitating the "Olmedieae" we obtain a rather homogeneous group which can be named and described as follows:

Tribus Castilleae C. C. Berg nom. nov.

\section{Based on Castilla Sessé in Cervantes}

Olmedieae Trécul, Ann. Sci. Nat. Bot. III. 8: 126. 1847, p.p. maj.

Castill(o)inae K. Schumann in Schumann \& Hollrung, Die Flora von Kaiser Wilhelms Land 41. 1889.

Antiarinae K. Schumann in Schumann \& Hollrung, Die Flora von Kaiser Wilhelms Land 41. 1889, nom. superfl.

Arbores vel frutices; rami spiraliter dispositi, sponte amputati; folia disticha; pili uncinati carentes; fibrae ligni plerumque septatae. Inflorescentiae unisexuales, capitatae, plerumque discoideae, involucro e bracteis imbricatis basaliter affixis. Stamina recta. Fructus perianthio aucto adnatus. Semina sine endospermio; cotyledones aequales, crassae; radicula brevis, apicalis.

Dioecious or monoecious trees or shrubs with spirally arranged self-pruning branches bearing the leaves in two rows; stipules rarely connate; uncinate hairs lacking; latex bitter, white or yellowish, turning pinkish or brown (to blackish); wood fibres usually septate; cardiac glycosides present in several genera. Inflorescences mostly in groups on shortened branches in the leaf axils, unisexual, usually discoid, with an involucre of imbricate, basally attached bracts; 

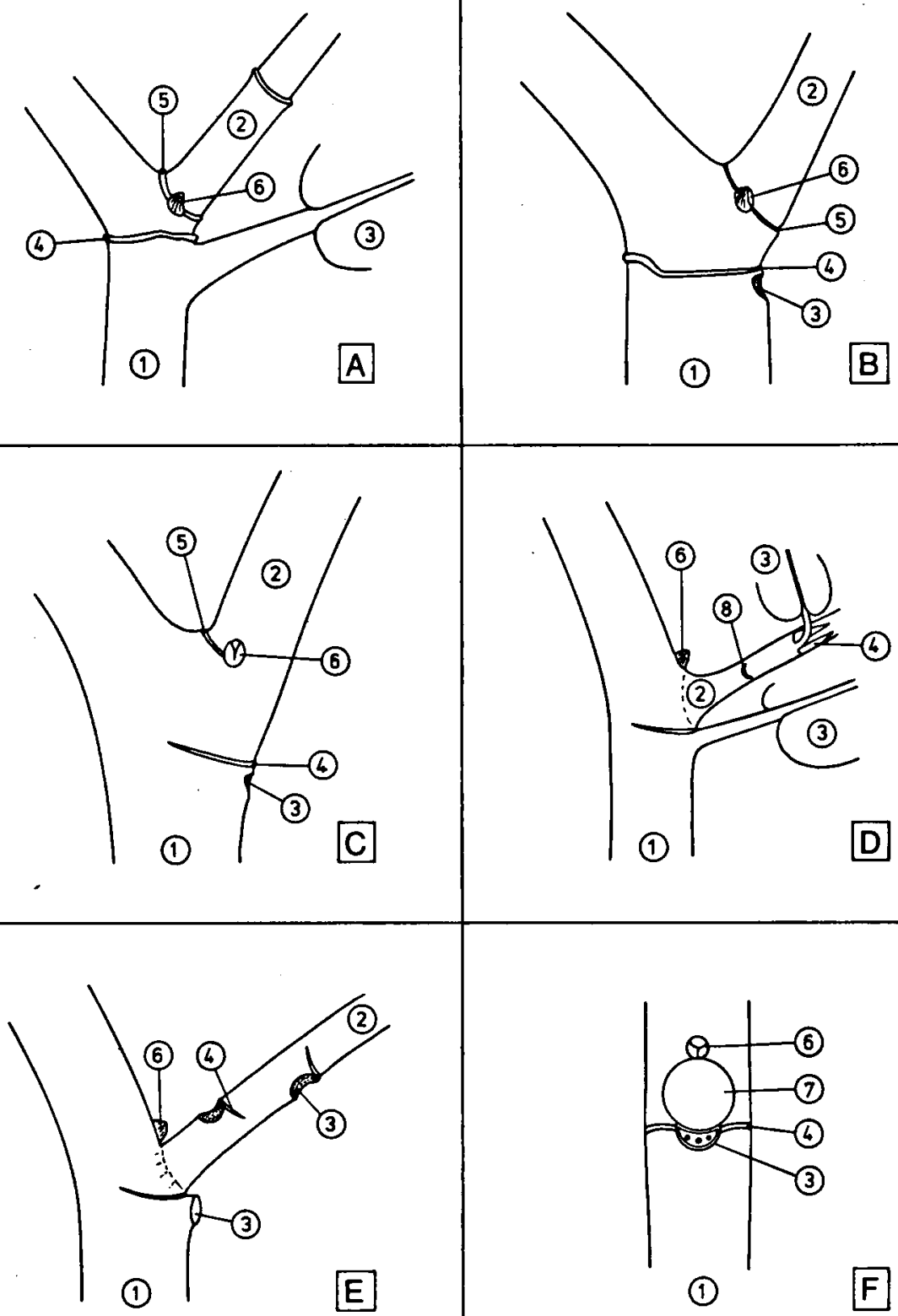

(1)

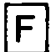

Fig. 2. Position of dormant buds forming permanent branches in Castilleae: $\mathbf{A}$. and B. Perebea xanthochyma (from Berg 358, Panama); C. Maquira costaricana (from Berg 317, Panama); D. Antiaris toxicaria (from no. 74-72, Botanical Garden, Utrecht); E. Antiaris toxicaria (from J. Léonard 471, Zaïre); F. Antiaris toxicaria (from Delvaux 659, Zaïre); 1. permanent branch; 2 . self-pruning-branch; 3 . leaf or leaf scar; 4 . stipule or scar of stipule; 5. scar of bud scale (= fused stipules); 6 . dormant bud; 7. scar of abscised branch; 8 . scar of scale leaf ( = fused stipules). 
perianth, if present and well-developed, (usually) with imbricate tepals; stamens basically straight; pistillodes rare; pistil more or less adnate to the perianth; fruit mostly (almost completely) adnate to the (fleshy) fruiting perianth; seeds large, without endosperm; vascular strands in the testa often not confined to a thickened part; embryo longitudinal; cotyledons (usually) equal and thick; radicle short and apical.

So defined the tribe comprises the genera Antiaris, Castilla, Heliocostylis, Maquira, Mesogyne, Naucleopsis, Perebea, and Pseudolmedia. Beside Olmedia the paleotropical genera Antiaropsis and Sparattosyce are excluded. The genus Hulletia (from Malaya) with capitate-involucrate inflorescences, regarded as a relative of Artocarpus by JARRET $(1959,1960)$, might prove to belong to this tribe, but presently available morphological and anatomical data are insufficient to provide a sound base for placing the genus satisfactorily, although Jarrett's conclusion may very well be correct.

In a comment on Antiaropsis SCHUMANN (1889) made a casual subdivision of the Olmedieae into Antiarinae and Castill(o)inae. This subdivision was hardly taxonomically founded and the groups are weakly defined.

\section{THE POSITION OF OLMEDIA}

The closest relative of Olmedia appears to be Trophis involucrata, a rare endemic species recently described from Costa Rica by BURGER (1973). It has fewflowered capitate and involucrate pistillate inforescences (possibly borne on short-shoots). The pistillate flowers with a more or less protracted tubular perianth resemble those of $O$. aspera. $T$. involucrata has racemose staminate inflorescences. The staminate fowers have valvate tepals and inflexed stamens, like the other species of Trophis s.str. They are similar to those of $O$. aspera. It is worth mentioning that a specimen of $O$. aspera was described as Trophis aurantiaca by HERZOG (1909).

\section{THE POSITION OF ANTIAROPSIS}

SChumann (1889) placed Antiaropsis, a genus of which only a single species is known, in the Olmedieae on the basis of the characters of the inflorescence. Except for the inflorescence Antiaropsis hardly has any distinctive characters in common with the members of the redefined tribe Castilleae.

The pistillate flowers have free tepals. The free fruit has a white (thin) fleshy dehiscent exocarp. The pistillode is well-developed. The inflorescences are not borne on short-shoots but are solitary in the leaf axils. A white fleshy dehiscent exocarp occurs in several members of the Dorstenieae (Dorstenia, Scyphosyce, and Utsetela) and several members of the Moreae, especially in taxa united under the broadly defined genus Streblus by CORNER (1962). The fleshy dehiscent exocarps push upward or even eject the endocarp bodies. In Antiaropsis the exocarp is probably too weak for pushing the endocarp body upward and 
may only assist in suddenly releasing the slippery endocarp body.

In spite of the loss of function the exocarp of Antiaropsis fruits is structurally similar to that of still functional ones, as in Phyllochlamys (Streblus sect. Phyllochlamys sensu Corner). The latter has uniflorous involucrate pistillate inflorescences, as in Antiaropsis decipiens var. parvifolia (see CORNER 1962). The capitate-involucrate staminate inflorescences of Phyllochlamys contain several flowers. The stamens are inflexed in Phyllochlamys, straight in Antiaropsis. Bracts and tepals of the pistillate inflorescence of Antiaropsis turn red.

Just as several Castilleae, Antiaropsis contains cardiac glycosides, but these substances are a'so found in Streblus asper (cf. Hegnauer 1969). Cardiac glycosides were not traced in Phyllochlamys and Sparattosyce (Bisset, unpublished work). The testa of the seeds of Antiaropsis has a distinct thickened vascularized part. The seed contains remains of endosperm. The embryo has a long radicle. The cotyledons, are large, rather flat, curved and plicate.

The data presently available suggest a rather close relationship between Phyllochlamys and Antiaropsis.

\section{THE POSITION OF SPARATTOSYCE}

On the basis of the urceolate inflorescence Sparattosyce has been inserted in the Ficeae. Corner (1962) transferred the genus to the Olmedieae.

Flower and embryo characters of Sparattosyce match those of Antiaropsis quite well, as far as could be concluded from the good description and drawings given by BUREAU (1869). The free fruit of Sparattosyce has a fleshy exocarp. The label of the collection H. S. McKee 3914 (L) of Sparattosyce dioica mentions the presence of open fruit-remains in the infructescence. This suggests the presence of dehiscent ectocarps, as in Antiaropsis.

The distinct resemblances in flowers and fruits suggest that Antiaropsis and Sparattosyce are rather closely related. It may be worth-while to compare the difference in the inflorescences of the Phyllochlamys - Antiaropsis - Sparattosyce-group with that in the Urticaceous genus Elatostema with capitate and often involucrate inflorescences but with ficiform inflorescences in E. ficoides (well illustrated in WEDDELL (1856-1857).

\section{ACKNOWLEDGEMENTS}

The author is much indebted to Dr. K. U. Kramer (Zürich) for critically reading the manuscript and for the correction of the English text, to Dr. G. T. Prance (Manaus - New York) and Dr. R. L. Dressler (Balbao, Panama) for their help in gathering in the field the data which led to this paper, to the Netherlands Foundation for Tropical Research (WOTRO) for a grant to defray a part of the expenses for field studies in Brazil, to my wife for the readiness to allow to spend a part of the family budget for covering the remainder of the expenses, to Dr. J. Koek-Noorman and Dr. A. M. W. Mennega for their co-operation in the study of the anatomical aspects. 


\section{REFERENCES}

Balllon, H. (1875-1876): Histoire des Plantes 6. (Ulmacées: 137-215). Paris.

BENTHAM, G. \& J. D. Hooker (1880): Genera Plantarum 3(1). (Urticaceae: 341-395). London. BERG, C. C. (1972): Flora Neotropica Monograph No. 7. Olmedieae and Brosimeae (Moraceae). New York.

- (1973): Some remarks on the classification and differentiation of Moraceae. Mededelingen van het Botanisch Museum en Herbarium van de Rijksuniversiteit te Utrecht. No. 386.

Bureau, E. (1869): Morées et Artocarpées de la Nouvelle Calédonie. Ann. Sci. Nat. Bot. V. 11: $364-382$.

Burger, W. C. (1973): Notes on the flora of Costa Rica 3. New species in the Moraceae. Phytologia 26(6): $421-434$.

Cook, O. F. (1903): The culture of the Central American rubber tree. U.S. Dept. Agr. Bureau Pl. Industry Bull. 49: 1-86, t. 1-18.

- (1911): Dimorphic branches in tropical crop plants: Cotton, Coffee, Cacao, the Central American Rubber tree, and the Banana. U.S. Dept. Agr. Bureau Pl. Industry Bull. 198 : $1-64$.

Corner, E. J. H. (1962): The classification of Moraceae. Gard. Bull. Singapore 19: 187-252.

EICHLER, A. W. (1875): Blüthendiagramme. Leipzig.

ENDLICHER, S. L. (1836-1840): Genera Plantarum. Wien.

Engler, G. H. A. (1889): In: Engler \& Prantl, Die natürlichen Pflanzenfamilien 3(1). (Moraceae: 66-98). Leipzig.

Hallé, F. \& R. A. A. Oldeman (1970): Essai sur Tarchitecture et la dynamique de croissance des arbres tropicaux. Paris.

Hegnauer, R. (1969): Chemotaxonomie der Pflanzen 5. (Moraceae 107-128). Basel - Stuttgart.

HerzoG, Th. (1909): Siphonogamae novae bolivienses in itinere per Boliviam orientalem ab auctore lectae. Repert. Sp. Nov. 7: 49-69.

JARRETT, F. M. (1959): Studies in Artocarpus and allied genera. Jour. Arnold Arb. 40: 1-37, 113-155, 298-368; 41: 73-140, 320-340.

LYNCH, R. I. (1877): On the disarticulation of branches. Jour. Linn. Soc. London Bot. 16: $180-183$.

MeNNEGA, A. M. W. \& M. LANZING-Vinkenborg (1977): On the wood anatomy of the tribe "Olmedieae" (Moraceae) and the position of the genus Olmedia R. \& P. Acta Bot. Neerl. 26: 1-27.

Millington, W. F. \& W. R. Chaney (1973): Shedding of Shoots and Branches. In: KozLOWSKI, Shedding of Plant Parts (p. 149-204). New York - London.

Ruiz, H. \& J. A. Pavon (1794): Florae Peruvianae et Chilensis Prodromus. Madrid.

Schumann, K. (1889): In: Schumann \& Hollrung, Die Flora von Kaiser Wilhelms Land. (Moraceae: 39-41.) Berlin.

TréCul, A. (1847): Sur la famille des Artocarpées. Ann. Sci. Nat. Bot. III. 8: 38-157.

TRIMEN, H. (1898): A handbook of the Flora of Ceylon 4. London.

Weddell, H. A. (1856-1857): Monographie de la famille des Urticées. Arch. Mus. Hist. Nat. Paris 9.

Went, F. A. F. C. (1897): Der Dimorphismus der Zweige von Castilloa elastica. Ann. Jard. Bot. Buitenzorg 14: 1-16, t. 1-3.

WIT, H. C. D. DE (1963): De Wereld der Planten 1. Den Haag. 